Alicja Lisowska, Agnieszka Florczak

Uniwersytet Wrocławski

\title{
Kultura organizacyjna instytutu naukowego. Studium kultury organizacyjnej Instytutu Politologii Uniwersytetu Wrocławskiego
}

DOI: 10.19195/1643-0328.21.7

Słowa kluczowe: organizacja, kultura organizacyjna, hierarchia, klan, adhokracja, rynek, zmiana kultury organizacyjnej

\section{Wprowadzenie}

„Żadne przedsiębiorstwo nie szczyci się dziś swoją niezmiennością czy podobieństwem do stanu sprzed dziesięciu lat. Stabilność częściej jest rozumiana jako przejaw stagnacji niż solidności, a przedsiębiorstwa, które nie zmieniają się i nie ulegają ewolucji, powszechnie uważa się za skostniałe"1. Lektura książki autorstwa Kima S. Camerona i Roberta E. Quinna, zawierającej powyższy cytat, oraz fakt, że większość badaczy zajmujących się obecnie organizacjami przyznaje, iż kultura przedsiębiorstwa ma ogromny wpływ na jego funkcjonowanie i efektywność, sprawiły, że postanowiłyśmy bliżej przyjrzeć się temu zagadnieniu w jednostce naukowo-dydaktycznej, która pozostaje naszym miejscem edukacji i pracy od około dwóch dekad.

Celem niniejszego artykułu jest prezentacja wyników badań przeprowadzonych w Instytucie Politologii Uniwersytetu Wrocławskiego (dalej jako IP), dotyczących modelu kultury organizacyjnej. W badaniach wykorzystano kwestionariusz OCAI (ang. Organisational Culture Assessment Instrument) umożliwiający określenie typu kultury organizacyjnej zgodnie z klasyfikacją Camerona i Quinna. Należy jednak wyraźnie podkreślić, iż jest to narzędzie zestandaryzowane, stosowane do badań w typowych organizacjach. Oznacza to, że część poruszanych zagadnień nie jest w stanie w pełni odzwierciedlić warunków pracy w Instytucie Politologii. Mając jednak tego świadomość, poprosiłyśmy respondentów o uwzględnienie specyfiki miejsca pracy w ramach udzielanych odpowiedzi.

${ }^{1}$ K.S. Cameron, R.E. Quinn, Kultura organizacyjna - diagnoza i zmiana. Model wartości konkurujących, przeł. B. Nawrot, Kraków 2006, s. 11. 
Artykuł składa się z dwóch zasadniczych części. Pierwsza ma charakter teoretyczny. Zdefiniowano w niej pojęcie kultury organizacyjnej, zaproponowano operacjonalizację pojęcia na potrzeby badania oraz przedstawiono cztery typy kultur organizacyjnych. Druga część artykułu ma natomiast wymiar empiryczny, gdyż scharakteryzowano w niej wykorzystane narzędzie, badaną populację oraz zaprezentowano wyniki badań przeprowadzonych w Instytucie Politologii. Całość artykułu kończy podsumowanie będące swego rodzaju diagnozą stanu obecnego kultur obowiązujących w IP.

\section{Podstawy teoretyczne badania}

\section{Kultura organizacyjna — rozważania definicyjne i operacjonalizacja pojęcia}

Kultura organizacji, obok strategii i struktury, zaliczana jest do głównych składników organizacji. Jednocześnie jest to pojęcie, które wzbudza wiele kontrowersji. Trudności związane z jego zdefiniowaniem można porównać do problemów, jakie pojawiają się przy doprecyzowywaniu terminu „kultura”. Alfred L. Kroeber i Clyde Kluckhohn wyodrębnili aż 164 definicje kultury ${ }^{2}$. W konsekwencji w literaturze przedmiotu nie ma jednej, powszechnie przyjętej definicji pojęcia "kultura organizacyjna”. Za Encyklopedia zarzadzania termin ten możemy określić jako: „normy społeczne i systemy wartości stymulujące pracowników, właściwy klimat organizacyjny, sposób zarządzania, podzielane znaczenia i symbole, schematy poznawcze, wymogi zachowania"3. Gary Dessler i Alvin Turner zdefiniowali pojęcie kultury organizacyjnej jako zbiór wartości, wierzeń, wzorów zachowań, zdolności pojmowania, założeń, norm, spostrzeżeń, emocji i uczuć, które są podzielane przez członków organizacji ${ }^{4}$. Czesław Sikorski postrzega zaś kulturę organizacyjną jako „zbiór norm społecznych i wartości, które są stymulatorami zachowań członków instytucji istotnych z punktu widzenia stosunków mających znaczenie dla realizacji określonego celu, a zachodzących w czasie i przestrzeni między ludźmi oraz między ludźmi i elementami aparatury”. Jest to również, według tego samego autora, „system nieformalnie utrwalonych w środowisku społecznym organizacji wzorów myślenia i działania, mających znaczenie dla realizacji formalnych celów organizacyjnych"6. Zdaniem Ricky’ego W. Griffina kultura organizacji to „zestaw wartości, które pomagają jej członkom zrozumieć, za czym organizacja się opowiada, jak pracuje, co uważa za słuszne. Kultura jest pojęciem

2 A.L. Kroeber, C. Kluckhohn, Culture: A critical review of concepts and definitions, „Papers of the Peabody Museum of American Archeology and Ethnology, Harvard University" XLVII, nr 1, Cambridge, Massachusetts 1952, http://www.pseudology.org/Psyhology/CultureCriticalReview1952a.pdf (dostęp: 9.05.2016).

${ }^{3}$ Kultura organizacyjna, [hasło w:] Encyklopedia zarządzania, https://mfiles.pl/pl/index.php/Kultura_organizacyjna (dostęp: 29.05.2016).

${ }^{4}$ G. Dessler, A. Turner, Human Resource Management in Canada, Scarborough, Ontario 1992, s. 22, cyt. za: B. Mikuła, Klimat organizacyjny a kultura organizacyjna - próba systematyzacji pojęć, „Zeszyty Naukowe Małopolskiej Wyższej Szkoły Ekonomicznej w Tarnowie” 2000, nr 3, s. 3.

5 C. Sikorski, Organizacja, kultura, mentalność pracowników, „Problemy Organizacji” 1985, nr 3-4, s. 254.

${ }^{6}$ C. Sikorski, Kultura organizacyjna, Warszawa 2002, s. 4. 
nieuprzedmiotowionym, które wymyka się obiektywnemu pomiarowi czy obserwacji”" Bogusz Mikuła przyjął dość ogólną definicję kultury organizacyjnej, uznając, że jest to „zbiór wartości, norm, poglądów podzielanych przez grupę ludzi, które warunkują ich postępowanie"8. Niektóre z przedstawionych definicji mogą budzić pewne zastrzeżenia, gdyż są sformułowane zbyt ogólnie, a tym samym nie oddają w pełni istoty zjawiska lub kwestionują możliwość przeprowadzenia badań z uwzględnieniem przyjętych kryteriów. Pokazuje to jednak rozbieżności i trudności w definiowaniu pojęcia. W części przeanalizowanych przez nas definicji elementami, przez których pryzmat doprecyzowywane jest pojęcie kultury organizacyjnej, są: zbiór wartości, przekonań, wierzeń, wzory zachowań - niekoniecznie wyrażone wprost i wpływające na zachowania ludzi w organizacji. Możemy zatem przyjąć, że kultura organizacyjna przejawia się w wartościach, dominujących stylach przywództwa, wykorzystywanych symbolach, metodach postępowania, stosowanych procedurach oraz rozumieniu sukcesu. Ujęcie wartościujące kultury dominuje w teorii organizacji i zarządzania.

Kultura organizacyjna może być także definiowana przez pryzmat sposobu działania, sposobu myślenia lub przez wskazywanie reguł odnoszących się do określonych obszarów życia społecznego organizacji ${ }^{9}$. Wskazane elementy stały się podstawą klasycznej już definicji Edgara H. Scheina, który przyjął, że kultura organizacyjna to „wzór podzielonych podstawowych założeń, wyuczonych przez grupę w toku rozwiązywania problemów jej zewnętrznej adaptacji i wewnętrznej integracji, działających wystarczająco dobrze, aby uważano je za wartościowe i wpojona nowym członkom jako właściwy sposób postrzegania, myślenia i odczuwania w odniesieniu do tych problemów"10.

Sikorski, opierając się na definicji kultury przyjętej przez Kroebera i Kluckhohna ${ }^{11}$, wyróżnił trzy grupy elementów istotnych dla kultury organizacyjnej. Są to:

- wzory myślenia,

- wzory zachowań,

- symbole ${ }^{12}$.

Dzięki określonym wzorom myślenia członkowie grupy otrzymują kryteria oceny zjawisk i sytuacji. Składają się na nie założenia kulturowe (mające charakter filozoficzny i światopoglądowy), wartości i normy społeczne. Wzory myślenia, w postaci norm, są konsekwencją przyjętej hierarchii wartości i występują często jako niepisane reguły

7 R.W. Griffin, Podstawy zarządzania organizacjami, przeł. M. Rusiński, Warszawa 1996, s. 116.

8 B. Mikuła, op. cit., s. 35.

9 A. Worach, Kultura organizacyjna, [w:] Zespót - Kultura - Projekt, red. W. Olejniczak, Szczecin 2009, s. 32.

10 E.H. Schein, Organizational Culture and Leadership, San Francisco-London 2004, s. 17. Szerzej na temat definiowania pojęcia „kultura organizacyjna” zob. też Ł. Sułkowski, Kulturowa zmienność organizacji, Warszawa 2002; J.A.F. Stoner, R.E. Freeman, D.R. Gilbert jr, Kierowanie, przeł. A. Ehrlich, Warszawa 1998, s. 189-196; STRATEGOR, Zarządzanie firma, strategie, struktury, decyzje, tożsamość, przeł. K. Bolesta-Kukułka, Warszawa 1995, s. 512-519.

11 Autorzy ci przyjęli, że kulturą są „wzorcowe sposoby myślenia, odczuwania i reagowania, przyswajane i przekazywane głównie przez symbole tworzone przez grupy ludzi i zawierające konkretyzacje w postaci artefaktów". A.L. Kroeber, C. Kluckhohn, op. cit., s. 24.

12 C. Sikorski, Kultura organizacyjna, s. 7-13. 
określające powinności. Wzory zachowań umożliwiają dobranie właściwych form reagowania na zjawiska i sytuacje. Są konsekwencją upowszechnienia postaw wynikających z określonych wzorów myślenia. Symbole upowszechniają i utrwalają natomiast wzory myślenia i zachowania wśród członków grupy. Utożsamiane są z instrumentami socjalizacji kulturowej (fizycznymi, językowymi, behawioralnymi i osobowymi) i pełnią funkcję komunikacyjną.

Jak zauważa Krystyna Serafin, kultura organizacyjna wpływa na wyniki pracy poszczególnych jednostek, wydajność organizacyjną, satysfakcję z pracy, poziom zaangażowania, strategię i realizację zadań, rekrutację i selekcję pracowników, poziom oporu wobec zmian wprowadzanych w organizacji i konfliktów, socjalizację i charakter interakcji, działania o charakterze innowacyjnym czy poziom sprzedaży. Ta sama autorka podkreśla, że kultura organizacyjna „służy eliminowaniu organizacyjnej dwuznaczności zachowań i promuje proefektywne zachowania pracowników firmy. Dzięki temu podzielają oni ukształtowane w firmie wzory zachowań i założenia"13.

Badania nad kulturą organizacyjną pozwoliły wyróżnić typy kultur organizacyjnych. Podobnie jak w przypadku definicji - nie ma jednej powszechnie przyjętej typologii. Sikorski zwraca uwagę, że najczęściej występują typologie jednowymiarowe, oparte na jednej zmiennej, akcentujące dwa alternatywne typy kultur ${ }^{14}$. W typologiach często stosowane są też macierze bipolarne o dwóch zmiennych. Tylko przykładowo wskazać możemy typologię Rogera Harissona, który opierając się na modelu przeciwstawnych wartości (indywidualizm-kolektywizm, zewnątrzsterowność-wewnątrzsterowność), wyróżnił kulturę władzy, roli, zadania (wsparcia), osoby-jednostki (sukcesu) ${ }^{15}$. Zmodyfikowaną wersję tej typologii przedstawił Charles Handy, wyróżniając kulturę władzy, roli, zadań i zamierzeń oraz kulturę indywidualności (ukierunkowaną na jednostkę) ${ }^{16}$. Do znanych typologii należy także podział przedstawiony przez Terrence’a E. Deala i Allana A. Kennedy’ego, w ramach którego wyróżniono kultury: indywidualistów, hazardzistów, zrównoważoną i rutyniarzy ${ }^{17}$.

${ }^{13}$ K. Serafin, Kultura organizacyjna jako element wspierający realizację strategii przedsiębiorstwa, „Studia Ekonomiczne. Zeszyty Naukowe Uniwersytetu Ekonomicznego w Katowicach” 2015, nr 222, s. 87.

${ }^{14}$ C. Sikorski, Kultura organizacyjna, s. 17-18.

15 Kultura władzy opiera się na osobie lidera (lub grupie liderów), który sprawuje władzę i podejmuje decyzje. Sprawdza się w małych organizacjach. Kultura ról charakteryzuje się wysokim stopniem zbiurokratyzowania, jasno określonymi rolami i stabilizacją. Kultura zadania nastawiona jest na integrację pracowników, pracę zespołową i elastyczność w przystosowywaniu się do zmiennych warunków, natomiast kultura osoby stawia na osiągnięcie jak najlepszych wyników przez jednostki przy jednoczesnym kreowaniu dobrej atmosfery w firmie. Por. R. Harrison, Understanding your organization's character „Harvard Business Review", maj-czerwiec 1972, s. 119-128, http://www.uulead.org/docs/orgcharacter.pdf (dostęp: 10.06.2016).

16 A. Worach, op. cit., s. 35-39. Kulturę władzy cechuje silna pozycja szefa, dobra atmosfera w organizacji i ograniczona do minimum liczba reguł. W kulturze ról członkowie organizacji działają wedle ustalonych zasad oraz procedur, a sama organizacja nastawiona jest na bezpieczeństwo i stabilizację. Cechą charakterystyczną kultury zadań jest powoływanie zespołów do wykonywania określonych działań. W kulturze indywidualności widoczna jest autonomia jednostek, a organizacja służy realizacji osobistych celów jej członków.

17 Szerzej na ten temat zob. T.E. Deal, A.A. Kennedy, Corporate Culture: The Rites and Rituals of Corporate Life, New York 1982, cyt. za: C. Sikorski, Kultura organizacyjna, s. 19. W kulturze indywidualistów duże 
W świetle powyższych rozważań na potrzeby badań pojęcie „kultura organizacyjna” zostało zdefiniowane zgodnie z propozycją Camerona i Quinna. Badacze ci określili kulturę organizacji jako zbiór wartości uważanych za oczywiste, niezwerbalizowanych założeń, wspólnych oczekiwań, definicji, elementów pamięci zbiorowej. W ich opinii kultura organizacyjna „odzwierciedla dominujące poglądy, określa poczucie tożsamości pracowników, dostarcza niepisanych, a często nie do końca uświadomionych zasad postępowania w miejscu pracy, wzmacnia trwałość systemu społecznego"18. Tym samym zostało przyjęte wartościujące ujęcie kultury organizacyjnej. Ponadto za podstawę analizy szczegółowej przyjęto zaproponowaną także przez Camerona i Quinna typologię kultur organizacyjnych.

\section{Typy kultur organizacyjnych wg K.S. Camerona i R.E. Qiunna}

Cameron i Quinn stworzyli typologię kultur organizacyjnych, w ramach której można wskazać cztery główne typy kultur, a mianowicie kulturę hierarchii, rynku, klanu i adhokracji ${ }^{19}$. Jest to modelowe ujęcie zagadnienia, co oznacza, iż nie wszystkie atrybuty poszczególnych rodzajów kultur muszą charakteryzować daną organizację. Co więcej, jak zauważają autorzy, model ten jest „niezwykle pomocny przy systematyzowaniu i interpretowaniu szerokiego wachlarza zjawisk występujących w organizacji” ${ }^{20}$. Cechuje go także wysoki stopień zgodności z powszechnie znanymi i akceptowanymi klasyfikacjami porządkującymi sposoby myślenia ludzi, wyznawane przez nich wartości, przyjmowane założenia oraz sposoby przetwarzania informacji ${ }^{21}$.

W kulturze hierarchii ${ }^{22}$ obowiązuje wysoki stopień sformalizowania i zhierarchizowania. W funkcjonowaniu organizacji duże znaczenie mają procedury, regulaminowo potwierdzone przepisy i zasady, które jednocześnie postrzegane są jako gwarant spójności organizacji. W konsekwencji w długiej perspektywie celem jest osiągnięcie trwałości, przewidywalności i efektywności. Przywódcy w organizacji pełnią funkcje koordynatorów, obserwatorów, organizatorów i charakteryzują się wysokim stopniem sprawności. Mają umiejętności koordynacji oraz organizacji pracy pozostałych człon-

znaczenie ma osobisty sukces pracowników. Członkowie organizacji powinni działać szybko i podejmować ryzykowne decyzje. Organizacja, w której dominuje typ kultury hazardzistów, nastawiona jest na szybkie działanie w krótkim czasie. Jednocześnie ważny jest rozwój kontaktów osobistych członków organizacji. Kulturę zrównoważoną cechuje spokój, porządek w działaniu, dobra wymiana informacji i długookresowe planowanie. Kultura rutyniarzy charakteryzuje się niechęcią do zmian, stabilizacją i dość wysokim stopniem sformalizowania.

18 K.S. Cameron, R.E. Quinn, op. cit., s. 24.

19 Przedstawiona dalej charakterystyka poszczególnych rodzajów kultur powstała na podstawie: ibidem, s. 41-49.

${ }^{20}$ Ibidem, s. 36.

${ }^{21}$ Ibidem, s. 38.

22 Jako przykłady kultury hierarchicznej wymienia się: sieć McDonald’s, Ford Motor Company, amerykański Departament Sprawiedliwości. Ten typ dominuje także w wielkich przedsiębiorstwach i w urzędach państwowych. 
ków. Kontrola w organizacji jest utrzymywana dzięki przepisom, wąskiej specjalizacji i scentralizowanym decyzjom.

Typ kultury rynku charakteryzuje się większym zorientowaniem na sprawy zewnętrzne, w tym na kształtowanie własnej pozycji w otoczeniu, niż na sprawy wewnętrzne. Oznacza to ukierunkowanie na transakcje z podmiotami zewnętrznymi (np. dostawcami, klientami, związkami zawodowymi i ciałami nadzorującymi) oraz zogniskowanie działania na ekonomicznych mechanizmach rynkowych, przede wszystkim na wymianie pieniężnej. Organizacje, w których dominuje ten typ kultury, koncentrują uwage na przeprowadzaniu transakcji (wymiana, sprzedaż, kontrakty) z innymi podmiotami i zdobywaniem przewagi konkurencyjnej na rynku. Długofalowym celem jest wzrost konkurencyjności i jak największa efektywność, nastawienie na pokonywanie konkurencji i utrzymanie pozycji lidera. Cel musi być jasno określony, a jego realizacja powinna opierać się na agresywnej strategii prowadzącej do wzrostu wydajności i zyskowności. Podstawowymi wartościami są konkurencyjność i wydajność. Otoczenie organizacji postrzegane jest jako wrogie, a klienci jako wymagający. Kierownictwo firmy ma za zadanie dbać o wydajność, zyski i wyniki. Preferowane cechy przywódców to bycie wymagającym i twardym.

Organizacje o klanowej kulturze swoje funkcjonowanie opierają na wspólnie wyznawanych wartościach oraz celach. Ich cechami wyróżniającymi są spójność, wysoki stopień uczestnictwa oraz duże poczucie wspólnoty. Spójność opiera się na lojalności i przywiązaniu do tradycji, silnych więzach i wysokim morale. Organizacja przypomina bardziej rodzinę niż przedsiębiorstwo, stara się stworzyć przyjazną atmosferę i troszczyć o pracowników. W przedsiębiorstwie funkcjonują częściowo niezależne zespoły robocze, które mogą mieć kompetencje do zatrudniania i zwalniania pracowników. Dominuje praca zespołowa, dążenie do zwiększenia zaangażowania pracowników i poczucie odpowiedzialności firmy za pracowników, uczestnictwo oraz konsensus. Nagradzanie odbywa się na podstawie osiągnięć zespołu (a nie pojedynczych pracowników). Zadaniem kierownictwa jest przekazywanie uprawnień pracownikom (występuje delegowanie uprawnień), zachęcanie do zaangażowania i lojalności. Przywódcy pełnią funkcje mentorów i opiekunów, a klienci traktowani są jak partnerzy.

Natomiast w organizacji o kulturze adhokracji najbardziej ceni $\operatorname{się}^{23}$ innowacje, które są podstawą sukcesu firmy, wprowadzanie nowych produktów i usług oraz reagowanie na zmiany. W organizacji kładzie się nacisk na elastyczność i innowacyjność prowadzące do zwiększenia zasobów i kreowania wizji przyszłości. Preferuje się ujarzmioną anarchię i zdyscyplinowaną wyobraźnię, brak scentralizowanego ośrodka władzy oraz zależności służbowej, brak schematu organizacyjnego, obiegu informacji czy systemu kontroli. Często obowiązuje tylko tymczasowy podział kompetencji, zakres obowiązków i zasady funkcjonowania, które szybko ulegają zmianie. Struktury organizacji są nietrwałe (zespoły robocze powoływane ad hoc, rozwiązywane po zakończeniu zadania). Wiąże się z tym przekazywanie władzy przez jednostki lub zespoły robocze (grupy zadaniowe) w zależności od pojawiającego się problemu, krótkotrwałe członkostwo i przy-

${ }^{23}$ Jest to typ kultury organizacji, która może istnieć wraz z typem kultury innego rodzaju. 
wództwo w zespołach. Liderzy (przywódcy) popierają przedsiębiorczość, kreatywność i poszukiwanie nowatorskich rozwiązań. Preferowane cechy pracowników to: duża zdolność przystosowania się, kreatywność, elastyczność, szukanie rozwiązań niestandardowych, ryzykownych i zdolność przewidywania rozwoju sytuacji. Ponadto organizacje cechujące się elementami kultury adhokracji są dynamiczne w działaniach i kreatywne. Przywódcy są wizjonerami, ryzykantami i innowatorami. Spójność organizacji zapewnia innowacyjność i chęć eksperymentowania. Jej celem jest utrzymanie pozycji lidera w określonej dziedzinie (wyrobów, usług, wiedzy), w dłuższej perspektywie - szybki wzrost i zdobywanie nowych zasobów. W organizacjach tego typu charakterystyczne jest nastawienie na produkcję unikatowych i trudnych do zastąpienia wyrobów i usług.

\section{Kultura organizacyjna Instytutu Politologii — diagnoza i wyniki badania}

\section{Opis i charakterystyka narzędzia badawczego oraz badanej populacji}

W badaniach wykorzystano zestandaryzowane narzędzie stworzone przez Camerona oraz Quinna, za pomocą którego można badać ważne elementy kultury organizacyjnej oraz określić jej typy. Narzędziem tym jest kwestionariusz OCAI, oparty na modelu wartości konkurujących ${ }^{24}$. Warto podkreślić, iż kwestionariusz został wykorzystany przez ponad tysiąc przedsiębiorstw do badania i opisywania funkcjonowania organizacji oraz różnego typu instytucji publicznych ${ }^{25}$.

Ankieta składa się z dwóch zasadniczych części. Pierwsza obejmuje zestaw pytań, za pomocą których możliwe jest określenie obowiązującego typu kultury organizacyjnej danego przedsiębiorstwa. Druga natomiast pozwala na określenie preferowanego przez pracowników typu kultury organizacji, który należałoby wdrożyć. Innymi słowy, pierwsza część badania dotyczy stanu faktycznego, druga - pożądanego. Na podstawie badania możemy zatem stworzyć profil kultury organizacji.

${ }^{24}$ Więcej na temat wartości konkurencyjnych zob. K.S. Cameron, R.E. Quinn, op. cit., s. 36-40.

25 Ibidem, s. 28. W Polsce za pomocą tego narzędzia badano np. instytucje samorządowe, administrację publiczną, jednostki organizacyjne Uniwersytetu Wrocławskiego. Por. M.A. Leśniewski, Wyznaczanie profilu kultur organizacyjnych z wykorzystaniem modelu K.S. Camerona i R.E. Quinna, na przykładzie urzędów gmin regionu świętokrzyskiego - wyniki badań ankietowych, „Studia i Prace Kolegium Zarządzania i Finansów" 2010, z. 104; L. Habuda, Organizacyjno-kulturowe orientacje samorządowców i demokratyzm polskiego terytorialnego samorzadu, [w:] Samorząd terytorialny na przełomie XX/XXI wieku, red. A. Lutrzykowski, M. Popławski, R. Gawłowski, Toruń 2010; A. Marek, Model wartości konkurujących w badaniu kultury organizacji samorzadowych, „Roczniki Ekonomii i Zarządzania” 6 (42), 2014, nr 2; J. Stompór-Świderska, Diagnoza kultury organizacyjnej uniwersytetu: elastyczne podejście do kierunków zmian i nowych wyzwań, [w:] Sukces $w$ zarządzaniu kadrami. Elastyczność w zarządzaniu kapitałem ludzkim. t. 2. Problemy zarządczo-ekonomiczne, red. T. Listwan, M. Stor, Wrocław 2012; eadem, Kultura organizacyjna instytutu naukowego w percepcji studentów. Diagnoza i nowe wyzwania, „Management” 16, 2012, nr 1. 
W każdej części ankiety respondenci odpowiadają na sześć podstawowych pytań, które odnoszą się do poszczególnych wymiarów kultury. Na ich podstawie otrzymujemy odpowiedź na pytanie, jak funkcjonuje nasza organizacja i jakie wartości ją charakteryzują.

W obydwu częściach kwestionariusza ankietowani odpowiadają na sześć pytań:

1. Jaka jest ogólna charakterystyka organizacji?

2. Jaki jest styl przywództwa w organizacji?

3. Jaki jest styl zarządzania pracownikami?

4. Co zapewnia spójność organizacji?

5. Na co kładzie się największy nacisk?

6. Jakie są kryteria sukcesu w organizacji?

Do każdego pytania przyporządkowano cztery odpowiedzi, pomiędzy które respondent rozdziela 100 punktów, w zależności od tego, w jakim stopniu dana odpowiedź odzwierciedla sytuację w badanej organizacji. Jednocześnie towarzyszy temu założenie, że najwięcej punktów przypisujemy odpowiedzi najtrafniej charakteryzującej sytuację. Suma punktów przydzielonych wszystkim odpowiedziom nie może być mniejsza lub większa niż 100. Odpowiedzi A, B, C, D odnoszą się do określonych typów kultury organizacyjnej.

Obliczanie wyników następuje przez zsumowanie wszystkich punktów przyznanych odpowiedziom A w odniesieniu do pytań dotyczących stanu obecnego, a następnie podzielenie tej sumy przez sześć. Analogiczne działanie wykonujemy dla pozostałych komponentów (B, C, D) oraz dla stanu pożądanego.

Badanie przy zastosowaniu kwestionariusza OCAI zostało przeprowadzone w kwietniu 2016 roku w Instytucie Politologii, który jest jednostką w ramach Wydziału Nauk Społecznych Uniwersytetu Wrocławskiego. W Instytucie zatrudnionych jest 54 pracowników, z czego 47 to pracownicy naukowo-dydaktyczni, pozostali zaś - administracyjni. Badaniu poddani zostali wyłącznie pracownicy należący do pierwszej grupy. Wynikało to $\mathrm{z}$ dwóch przyczyn. Po pierwsze pracownicy administracyjni stanowili zbyt małą liczebnie grupę, aby badania były reprezentatywne. Po drugie, i to już można uznać za mniej istotną okoliczność, zbyt mała liczebność badanej populacji mogłaby się wiązać z łatwością przypisania odpowiedzi do ankietowanych osób, co jest sprzeczne z zasadą anonimowości i niezgodne z zasadami etyki obowiązującymi przy tego typu badaniach. Spośród wszystkich pracowników naukowo-dydaktycznych zaproszonych do badania ankietę wypełniło 37 pracowników, co stanowi 79\% badanej populacji.

Biorąc pod uwagę specyfikę organizacji poddanej badaniu, do narzędzia badawczego wprowadzono dwa elementy uzupełniające, wykorzystane jako zmienne niezależne, a mianowicie płeć badanych i zajmowane stanowisko. Uwzględnienie przez autorów kwestionariusza dodatkowych okoliczności waloryzujących udzielone odpowiedzi wynikało z przyjęcia założenia, że istotne znaczenie zarówno dla funkcjonowania organizacji, jaką jest instytut naukowy, jak i zarządzania nią ma zajmowane stanowisko. Przyjmując natomiast drugą hipotezę, badacze wyszli w założenia, iż płeć jest istotnym predykatorem w kształtowaniu relacji międzyludzkich oraz dokonywaniu oceny poszczególnych rodzajów zachowań współpracowników. 


\section{Diagnoza i wyniki badania}

\section{A. Profil kultury organizacyjnej}

Analiza danych uzyskanych w ramach przeprowadzonego badania prowadzi do jednoznacznego wniosku, że pracownicy IP jako dominujący typ kultury organizacyjnej wskazują hierarchię. Dla dwóch typów kultury - rynku i klanu - średnie osiągnęly zbliżony poziom, najmniej razy wskazań otrzymała zaś kultura adhokracji (zob. tab. 1 i ryc. 1).

Tabela 1. Ogólna charakterystyka organizacji

\begin{tabular}{l|c|c}
\hline \multicolumn{1}{c|}{$\begin{array}{c}\text { Typ kultury } \\
\text { wyniki }\end{array}$} & Stan obecny & Stan pożądany \\
\hline A - klan & 21,62 & 33,37 \\
\hline B - adhokracja & 16,08 & 33,24 \\
\hline C - rynek & 24,67 & 22,83 \\
\hline D - hierarchia & 37,62 & 10,40 \\
\hline
\end{tabular}

Źródło: Opracowanie własne.

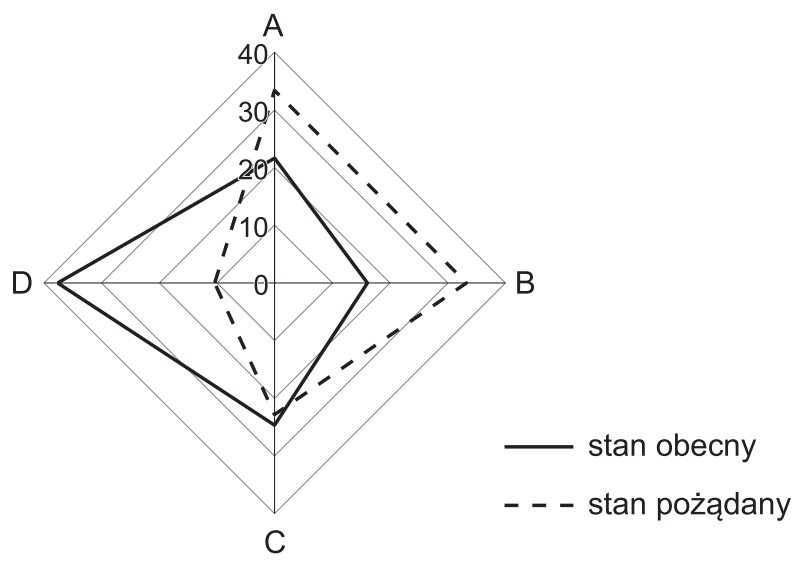

Rycina 1. Profil kultury organizacyjnej dla ogólnej charakterystyki organizacji

Źródło: Opracowanie własne.

Na podstawie wyników badań można stwierdzić, iż zdaniem pracowników w IP obowiązuje ścisła hierarchia i kontrola. Kultura organizacji zorientowana jest na sprawy wewnętrzne i cechuje ją stałość. Pracownicy funkcjonują w wysoce sformalizowanym i zhierarchizowanym środowisku. To przede wszystkim procedury określają zakres wykonywanych czynności. Wartością jest utrzymanie funkcjonowania organizacji bez zbędnych zakłóceń. Organizacja dąży do trwałości, przewidywalności i efektywności. 
Spójność zapewniają regulaminy, przepisy i zasady, a sprawni przywódcy są dobrymi koordynatorami i organizatorami.

Takie stanowisko charakteryzowało wszystkich respondentów, bez względu na płeć oraz zajmowane stanowisko. Oznacza to zatem, iż kultura hierarchii w ogólnym funkcjonowaniu Instytutu jest zauważalna zarówno przez mężczyzn, jak i kobiety oraz przez profesorów i adiunktów.

Wskazywany przez badanych obecny stan kultury organizacyjnej IP znacząco różni się od stanu pożądanego w zakresie ogólnej charakterystyki organizacji. W stanie pożądanym pracownicy zdecydowanie wskazują na potrzebę istnienia kultury klanu i adhokracji, a następnie rynku. Najmniej pożądana jest kultura hierarchii. Takie stanowisko zajęły zarówno kobiety, jak i mężczyźni - wszyscy pracownicy, bez względu na stanowisko. Jednakże w przypadku zmiennej „stanowisko” warto zwrócić uwagę na następującą prawidłowość: wśród osób na stanowisku profesora zdecydowanie więcej wskazań dotyczyło kultury klanu niż adhokracji (47,14 wskazań na rzecz klanu i 29,28_wskazań na rzecz adhokracji ${ }^{26}$ ). Tak dużej rozbieżności nie zauważono w przypadku adiunktów. Przy charakterystyce organizacji dla adiunktów w porównywalnym zakresie ważna okazała się zarówno kultura klanu, jak i adhokracji (32,4:35,4 wskazań).

Analizowane dane świadczą o tym, że badani zamiast ścisłej hierarchii i kontroli preferują w kulturze organizacyjnej IP szeroko rozumianą wspólnotowość charakteryzującą kulturę klanu oraz innowacyjność będącą atrybutem kultury adhokracji. W pierwszym przypadku istota organizacji winna skupiać się na spójności miejsca pracy, możliwości funkcjonowania w oparciu o przyjazną atmosferę, przypominającą nawet tę rodziną, oraz na stwarzaniu warunków pracy sprzyjających współpracy w trosce o pracowników. Natomiast kultura adhokracji w przypadku charakterystyki organizacji to przede wszystkim wskazywanie na potrzebę wprowadzania nowych rozwiązań organizacyjnych oraz reagowanie na zmiany w otoczeniu. Zdaniem pracowników w Instytucie powinno się delegować zadania w zależności od pojawiającego się problemu oraz powoływać zespoły robocze ad hoc, które będą rozwiązywane po zakończeniu zadania. Jednocześnie pracownicy wskazali na potrzebę wprowadzania rozwiązań niestandardowych, nawet związanych z podejmowaniem ryzykownych działań i na konieczność przewidywania i projektowania przez władze Instytutu sytuacji i przyszłości.

${ }^{26} \mathrm{~W}$ dalszej części artykułu wartości tego typu będą zapisywane skrótowo (w tym przypadku $47,14: 29,28)$. 


\section{B. Styl przywództwa w organizacji ${ }^{27}$}

Wyniki badań w zakresie stylu przywództwa w Instytucie w ramach stanu obecnego wskazują na nastawienie na kulturę hierarchii i klanu. W dalszej kolejności znalazły się wskazania odwołujące do kultury rynku i adhokracji (zob. tab. 2 i ryc. 2).

Tabela 2. Styl przywództwa w organizacji

\begin{tabular}{l|c|c}
\hline \multicolumn{1}{c|}{$\begin{array}{c}\text { Typ kultury } \\
\text { wyniki }\end{array}$} & Stan obecny & Stan pożądany \\
\hline A - klan & 31,48 & 23,89 \\
\hline B - adhokracja & 12,70 & 30,75 \\
\hline C - rynek & 20,81 & 13,51 \\
\hline D - hierarchia & 32,29 & 31,83 \\
\hline
\end{tabular}

Źródło: Opracowanie własne.

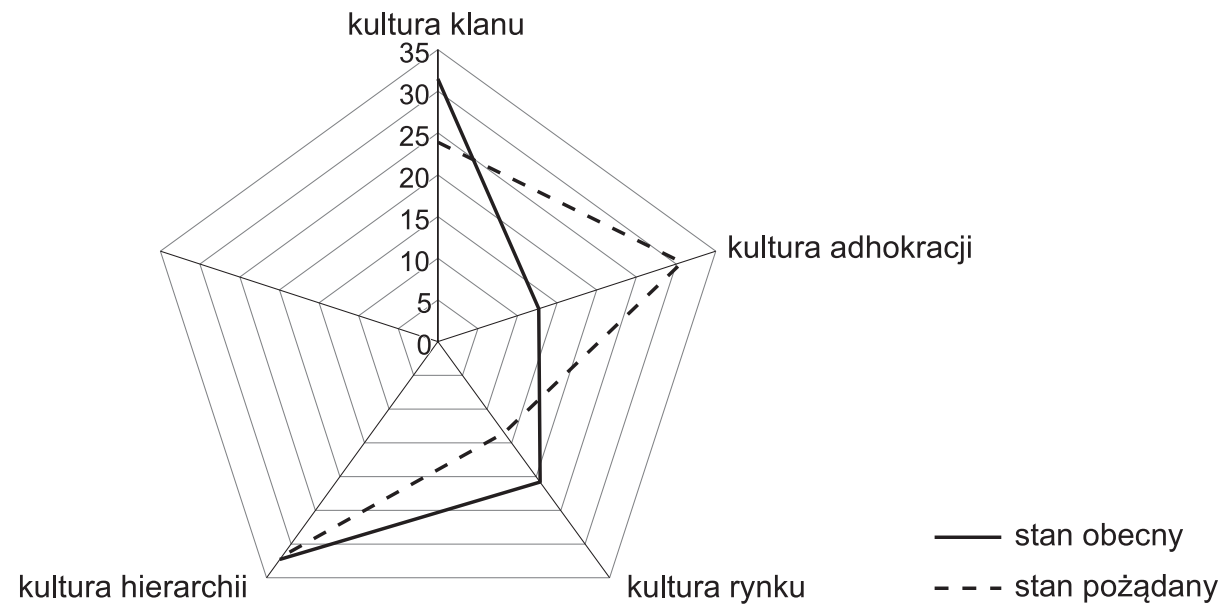

Rycina 2. Profil kultury organizacyjnej dla stylu przywództwa w organizacji

Źródło: Opracowanie własne.

W świetle tak udzielonych odpowiedzi można stwierdzić, że obowiązujący styl przywództwa w IP jest oparty na hierarchiczności i zbiurokratyzowaniu, regulaminach oraz programach pozwalających na sprawne organizowanie pracy i jej warunków w celu osią-

27 K.S. Cameron i R.E. Quinn w kwestionariuszu OCAI posługują się terminem leadership, który w polskim wydaniu został przetłumaczony jako „przywództwo”. Autorki zachowały terminologię obowiązującą w polskim tłumaczeniu, choć można się zastanawiać, czy bardziej trafnym terminem nie byłoby „zarządzanie". Por. K.S. Cameron, R.E. Quinn, Diagnosing and Changing Organizational Culture Based on the Competing Values Framework, The Jossey-Bass Business \& Management Series 2006, file://C:/Users/Agunia/ Downloads/Diagnosing\%20and\%20changing\%20organizational\%20culture\%20Based\%20on\%20the\%20 competing\%20values\%20framework\%20(1).pdf (dostęp: 24.08.2016). 
gania wyników. W ramach tego stylu przywódców charakteryzują wysoki stopień sprawności, dobra koordynacja pracy i zdolności organizatorskie. Jednocześnie obok hierarchicznego stylu przywództwa w IP zauważalne przez pracowników jest przywództwo utożsamiane ze służeniem radą i pomocą, traktowaniem pracowników jako partnerów, zachęcaniem do zaangażowania $\mathrm{w}$ pracę, które następnie jest nagradzane. Jest to styl charakterystyczny dla kultury klanu, którego cechą swoistą jest również delegacja zadań i uprawnień dla pracowników.

Wskazane przez badanych odpowiedzi dowodzą, iż sposób przewodzenia w Instytucie jest oceniany z perspektywy dwóch różnych stylów. Istotne jest też to, że porównywalna liczba osób wskazywała na przeciwstawne rodzaje przywództwa w miejscu pracy. Biorąc pod uwagę wartości wskazań, zastanawiające jest, iż w ramach jednego miejsca pracy występują tak rozbieżne oceny stylu przywództwa. Z rozkładów odpowiedzi wynika wyraźnie, że nie jest to determinowane zmienną „płeć”, gdyż nie różnicowała ona wyników badania w istotnym zakresie.

Zdecydowanie większy wpływ na różnice w występujących ocenach ma zajmowane stanowisko. Okazuje się bowiem, iż osoby na stanowisku profesora częściej wskazywały na kulturę hierarchii niż klanu, natomiast adiunkci odwrotnie (zob. ryc. 3). Jednakże, co trzeba podkreślić, właściwa interpretacja występujących rozbieżności wymagałaby pogłębionych badań.

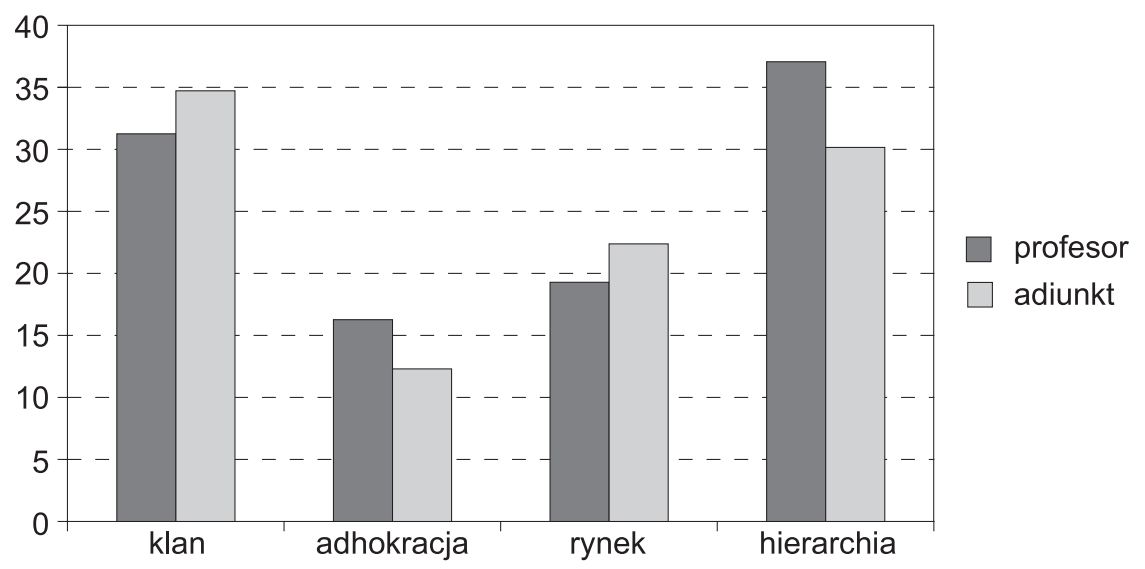

Rycina 3. Ocena stylu przywództwa w IP ze względu na zajmowane stanowisko

Źródło: Opracowanie własne.

Dokonując analizy stanu pożądanego, można stwierdzić, iż wskazywana jako dominująca $\mathrm{w}$ ramach stanu obecnego kultura hierarchii jest również pożądanym rodzajem kultury przywództwa w IP. Wydaje się zatem, że pracownicy są świadomi ważności spraw administracyjno-organizacyjnych w zarządzaniu Instytutem, dlatego też kultura hierarchii ma nadal istotne znaczenie w profilu pożądanego stylu przywództwa. Na podstawie uzyskanych wyników można też wnioskować, że pożądane zarządzanie to przede wszystkim nacisk na sprawne funkcjonowanie oraz dbałość o zaangażowanie i rozwój. Takie 
stanowisko cechowało częściej mężczyzn aniżeli kobiety (33,76:24), co odzwierciedla większą potrzebę kontroli i koordynacji wśród mężczyzn niż wśród kobiet.

Jednocześnie w ramach stanu pożądanego dominująca, zdaniem badanych, kultura klanu w obecnym profilu organizacji w odniesieniu do stylu przywództwa wyraźnie traci na rzecz kultury adhokracji. Wybór przez respondentów tego rodzaju kultury organizacyjnej dowodzi, iż preferowane style przywództwa wzajemnie się wykluczają. Z jednej strony pracownicy oczekują wdrożenia w życie rozwiązań swoistych dla kultury hierarchii, z drugiej - porównywalna liczba pracowników IP wskazuje na potrzebę implementacji atrybutów kultury adhokracji. Odwołujący się do cech kultury adhokracji pracownicy Instytutu Politologii zwracają uwagę na potrzebę zarządzania ich miejscem pracy w sposób zdecentralizowany oraz na ograniczenie zależności służbowych. Osoby zarządzające Instytutem winno cechować wizjonerstwo, gotowość do podejmowania rozwiązań zarówno ryzykownych, jak i innowacyjnych. Co więcej, osoby zajmujące stanowiska zarządcze winny przejawiać zdolności do zdyscyplinowanej wyobraźni. Są to konkretne oczekiwania stawiane osobom zarządzającym IP, które nie tylko wymagają zdecydowanych działań, lecz także umiejętności perspektywicznego myślenia.

Preferencje dotyczące tego stylu zarządzania występowały częściej u kobiet niż u mężczyzn. Taki rozkład odpowiedzi koresponduje z charakterystycznymi dla kobiet potrzebami projektowania przyszłości w oparciu o zmieniającą się rzeczywistość. Jasno określone potrzeby respondentek są w znacznej mierze odzwierciedleniem odgrywanych przez nie ról w sferze społecznej, w tym - prywatnej. Role odgrywane przez kobiety sprowadzają się między innymi do konieczności sprawnego zarządzania środowiskiem rodzinnym, w których podejmowane są często decyzje nie tylko karkołomne, ze względu na sytuacje, lecz także wyjątkowe. Wykształcony w życiu prywatnym sposób funkcjonowania zostaje zatem przeniesiony na płaszczyznę aktywności zawodowej, czego konsekwencją są określone oczekiwania.

Na trzecim miejscu znalazł się styl przywództwa związany z kulturą klanu. Ponad 1/5 pracowników IP wskazała, iż w pożądanym przez nich stylu zarządzania występuje potrzeba zorientowania na ludzi, umiejętności zarządzania zespołami, rozwiązywania konfliktów i szukania konsensusu. Co więcej, pożądane są również otwartość na problemy pracownicze, atmosfera wzajemnego zaufania, wysoki poziom zaangażowania w funkcjonowanie Instytutu oraz poczucie odpowiedzialności osób zarządzających za pracowników.

W stanie pożądanym kultura klanu, w ramach której przywódcy przywiązują wagę do umiejętności rozwiązywania konfliktów oraz łagodzenia stanów napięć w miejscu pracy, a także zarządzania relacjami międzyludzkimi, jest zdecydowanie częściej wybierana przez adiunktów niż profesorów.

\section{Styl zarządzania pracownikami}

Rozkład odpowiedzi odnoszących się do bieżącego stylu zarządzania pracownikami IP wskazuje, iż dominuje styl kultury hierarchii (zob. tab. 3 i ryc. 4). Na taki styl zarządzania pracownikami zwracały uwagę zarówno kobiety, jak i mężczyźni, a także zarówno 
profesorowie, jak i adiunkci. Jednakże warto podkreślić, iż choć przedstawiciele obu płci wskazywali na występowanie przede wszystkim stylu zarządzania zasobami ludzkimi opartego na kulturze hierarchii, to częściej takie stanowisko wyrażali mężczyźni aniżeli kobiety. Na kolejnych miejscach znalazły się opinie wskazujące na zarządzanie pracownikami w oparciu o atrybuty kultury klanu i adhokracji. Warto podkreślić, że zarówno w odniesieniu do stylu przywództwa, jak i stylu zarządzania dominującymi typami kultury są klan i hierarchia. Jednakże w przypadku stylu przywództwa oba typy kultury mają niemal jednakową liczbę wskazań (por. tab. 2), natomiast w przypadku stylu zarządzania widzimy bardzo dużą dysproporcję wskazań $(45,94$ - hierarchia, 20,27 - klan). Dodatkowo należy podkreślić, że adhokracja jest wskazywana równie często jak kultura klanu.

Tabela 3. Styl zarządzania pracownikami

\begin{tabular}{l|c|c}
\hline \multicolumn{1}{c|}{$\begin{array}{c}\text { Typ kultury } \\
\text { wyniki }\end{array}$} & Stan obecny & Stan pożądany \\
\hline A - klan & 20,27 & 34,45 \\
\hline B - adhokracja & 19,59 & 34,45 \\
\hline C - rynek & 14,18 & 15,81 \\
\hline D - hierarchia & 45,94 & 15,54 \\
\hline
\end{tabular}

Źródło: Opracowanie własne.

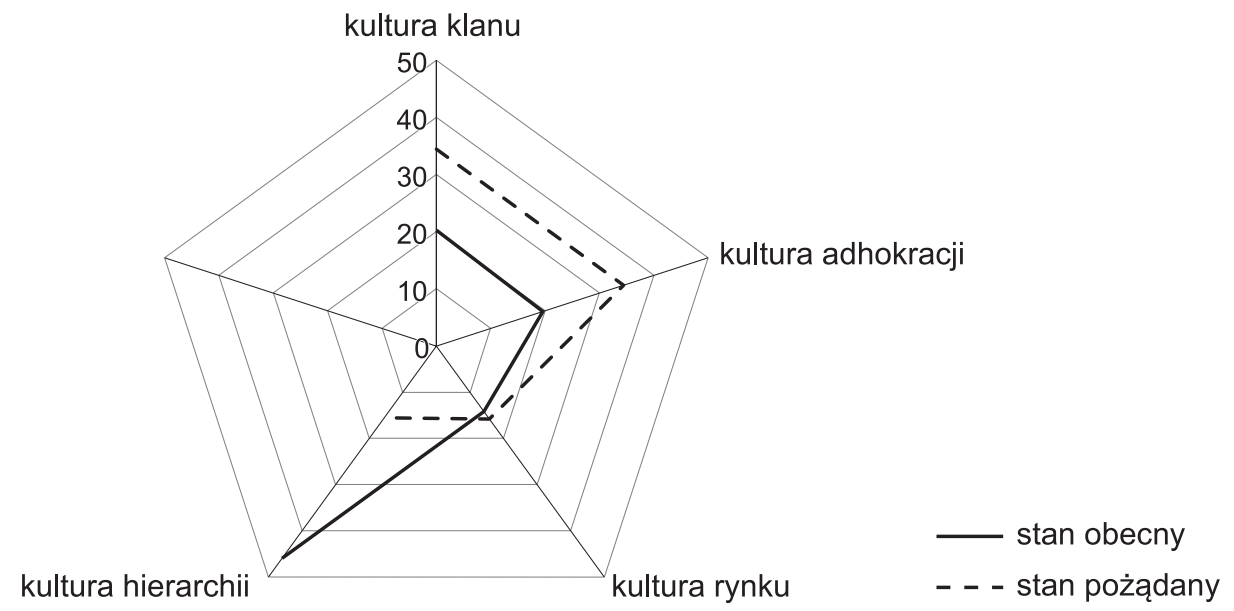

Rycina 4. Profil kultury organizacyjnej dla stylu zarządzania pracownikami

Źródło: Opracowanie własne.

O ile występują określone analogie pomiędzy oceną bieżącego stylu przywództwa w IP i stylu zarządzania pracownikami, o tyle w przypadku stanu pożądanego mają miejsce określone różnice. 
Stan pożądany w przypadku zarządzania pracownikami to atrybuty kultury klanu i adhokracji. Wszyscy pracownicy, bez względu na płeć i zajmowane stanowisko wyrazili potrzebę występowania $\mathrm{w}$ miejscu pracy nie tylko decentralizacji zarządzania i dynamicznego podziału obowiązków (często tymczasowego), ze względu na występujące sytuacje, lecz także bardziej przyjaznej atmosfery, która sprzyjałaby elastyczności zarządzania. W odczuciu pracowników dążenie do większego zaangażowania powinno zostać osiągnięte za pomocą adekwatnego odpowiadania na ich potrzeby oraz wprowadzenia mechanizmów opartych na wypracowywaniu konsensusów w działaniu Instytutu jako całości. Ponadto na podstawie analizy wyników można wnioskować, że pożądane zarządzanie zasobami to odejście od przewidywalności na rzecz elastyczności warunkowanej pracą zespołową oraz oryginalnością i innowacyjnością.

\section{Zapewnienie spójności organizacji}

Zdaniem pracowników IP najważniejszą rolę w zapewnieniu spójności w Instytucie odgrywa, po raz kolejny, kultura hierarchii, a następnie klanu, rynku i adhokracji (zob. tab. 4 i ryc. 5). Oznacza to zatem, iż spójność IP jest efektem przestrzegania ściśle określonych reguł postępowania zawartych $\mathrm{w}$ regulaminach i zasadach, klarownej i silnie zaznaczonej strukturze oraz jednoznacznie wytyczonego podziału obowiązków. W znacznej mierze spójność Instytutu opiera się na terminowości działań oraz na przestrzeganiu harmonogramów. Powyższe stanowisko charakteryzowało pracowników bez względu na płeć i zajmowane stanowisko.

Tabela 4. Spójność organizacji

\begin{tabular}{l|c|c}
\hline \multicolumn{1}{c|}{$\begin{array}{c}\text { Typ kultury } \\
\text { wyniki }\end{array}$} & Stan obecny & Stan pożądany \\
\hline A - klan & 31,21 & 37,83 \\
\hline B - adhokracja & 14,32 & 32,83 \\
\hline C - rynek & 15,67 & 17,16 \\
\hline D - hierarchia & 38,78 & 13,37 \\
\hline
\end{tabular}

Źródło: Opracowanie własne.

Dokonując wskazań odnośnie do stanu pożądanego, pracownicy zwrócili uwagę na odmienne elementy służące spójności w miejscu pracy. Zdaniem badanych podstawą powinna być kultura organizacyjna charakterystyczna dla kultury klanu i adhokracji. Takie stanowisko deklarowali wszyscy badani, bez względu na płeć i zajmowane stanowisko.

Wyartykułowane $w$ ramach określonych typów kultur organizacyjnych preferencje badanych dowodzą, iż pożądanym modelem funkcjonowania jest współpraca oraz wysoki stopień współuczestnictwa. Pracownicy IP chcieliby własną aktywność ogniskować wokół jasno określonych wartości konstytuujących funkcjonowanie w miejscu pracy, a także częściej pracować zespołowo. Istotnym elementem jest też potrzeba określenia 


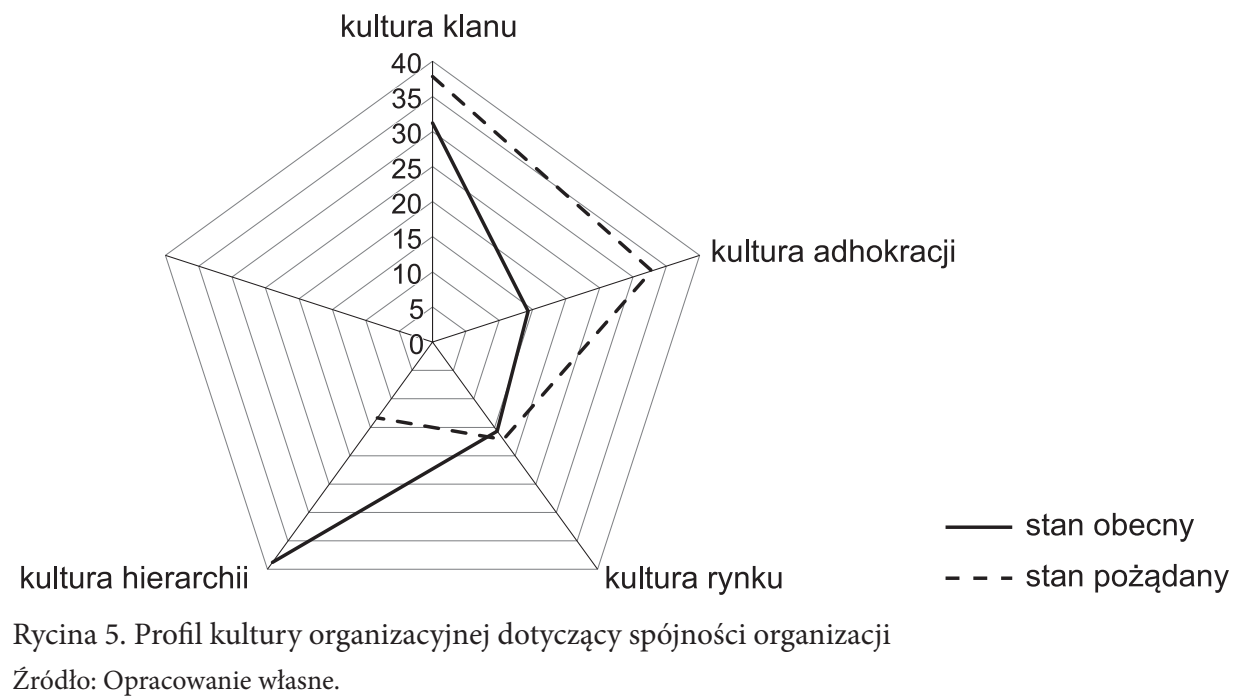

wspólnych celów, a następnie poczucie jedności w dążeniu do ich realizacji. Jednocześnie pracowników IP charakteryzuje przekonanie, że spójność organizacji przejawia się w chęci eksperymentowania i wprowadzania nowatorskich rozwiązań. Wszelkiego rodzaju zmiany byłyby możliwe, pracowników Instytutu charakteryzuje bowiem występowanie silnych więzi zarówno organizacyjnych, jak i personalnych. Badani uważają jednak, że nie ma możliwości wprowadzania zmian ze względu na istnienie procedur i regulaminów, w istotnym zakresie utrudniających realizację pożądanych przeobrażeń.

Trzeba podkreślić, iż gotowość do wprowadzania zmian jest silnie związana z przekonaniem, że przemiany powinny przebiegać stopniowo, przy uwzględnieniu opinii i sugestii członków organizacji. Artykułowanie przez badanych potrzeby współdecydowania za wprowadzane zmiany jest efektem przywiązywania przez nich wagi do tradycji, co jest też elementem cechy kultury klanu.

\section{E. Na co kładzie się nacisk w organizacji}

To, na co kładzie się nacisk w Instytucie Politologii, przejawia się w atrybutach kultury hierarchii (44,45 wskazań). Na drugim miejscu respondenci wskazali kulturę klanu. Zdaniem badanych podstawą funkcjonowania jest praca Instytutu przebiegająca bez żadnych zakłóceń. Pracownicy poddawani są różnego rodzaju kontroli, a organizacja nastawiona jest na utrzymanie niezmienności - zarówno w aspekcie funkcjonowania, jak i zarządzania. Jednocześnie zdecydowanie mniejszy odsetek pracowników zauważa, że w Instytucie akcentuje się potrzebę rozwoju osobistego, przywiązuje wagę do rozwoju pracowników, a w miejscu pracy panuje atmosfera otwartości i współuczestnictwa. Zauważalne jest też zaangażowanie współpracowników w swoją pracę. 
Tabela 5. Tabela wyników dotycząca tego, na co się kładzie nacisk w organizacji

\begin{tabular}{l|c|c}
\hline \multicolumn{1}{c|}{$\begin{array}{c}\text { Typ kultury } \\
\text { wyniki }\end{array}$} & Stan obecny & Stan pożądany \\
\hline A - klan & 22,83 & 37,70 \\
\hline B - adhokracja & 19,05 & 35,81 \\
\hline C - rynek & 13,91 & 15 \\
\hline D - hierarchia & 44,45 & 11,48 \\
\hline
\end{tabular}

Źródło: Opracowanie własne.

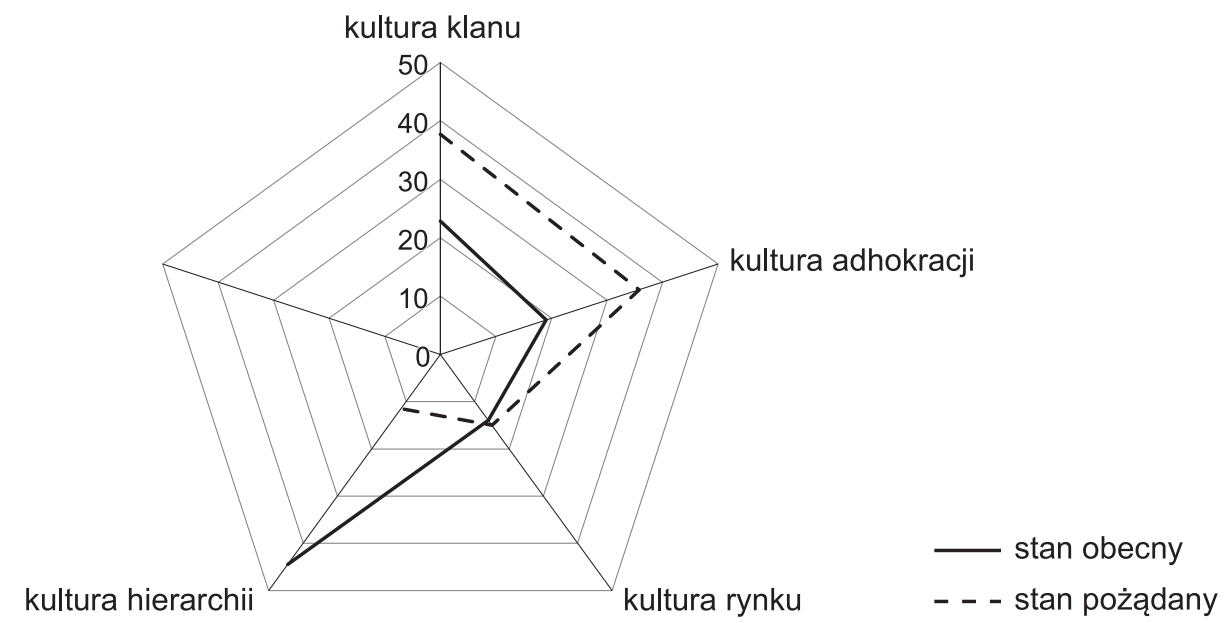

Rycina 6. Profil kultury organizacyjnej dotyczący tego, na co kładzie się nacisk w organizacji

Źródło: Opracowanie własne.

Elementy związane z kulturą hierarchii oraz klanu, które obecnie stanowią podstawę tego, na co kładzie się nacisk w IP, były częściej wskazywane przez mężczyzn aniżeli kobiety. Zauważalne rozbieżności wystąpiły także w odniesieniu do zmiennej, jaką jest zajmowane stanowisko. Dokonując oceny stanu bieżącego, można stwierdzić, że na atrybuty kultury hierarchii oraz klanu częściej zwracali uwagę adiunkci niż profesorowie (zob. ryc. 7). Fakt, iż elementy związane z możliwością rozwoju osobistego były akcentowane przez adiunktów, jest naturalną konsekwencją określonego etapu rozwoju kariery zawodowej. Adiunkci zauważają istniejące w pracy możliwości i cenią sobie występowanie tego rodzaju okoliczności. Jednocześnie częstsze odwoływanie się przez nich do komponentów kultury hierarchii może wskazywać na doświadczanie szczególnych jej atrybutów, na przykład kontroli.

Biorąc pod uwagę wyniki odnoszące się do stanu oczekiwanego, można stwierdzić, iż badani chcieliby, aby najistotniejsze dla Instytutu były cechy odnoszące się do kultury klanu i adhokracji. W praktyce powinno się to przejawiać w położeniu nacisku na rozwój osobisty pracowników, przyjazną atmosferę w miejscu pracy, a także zaufanie, otwartość i współuczestnictwo, co jest charakterystyczne dla kultury klanu. Natomiast 
zwrócenie uwagi przez badanych na kulturę adhokracji sprowadza się do dostrzegania potrzeby zwiększonego nacisku na zdobywanie nowych zasobów i podejmowanie przez organizację i jej pracowników, nowych wyzwań. Cenne powinno być też poszukiwanie innowacyjnych rozwiązań oraz możliwości, które pozwolą Instytutowi zdobyć pozycję lidera w określonej dziedzinie.

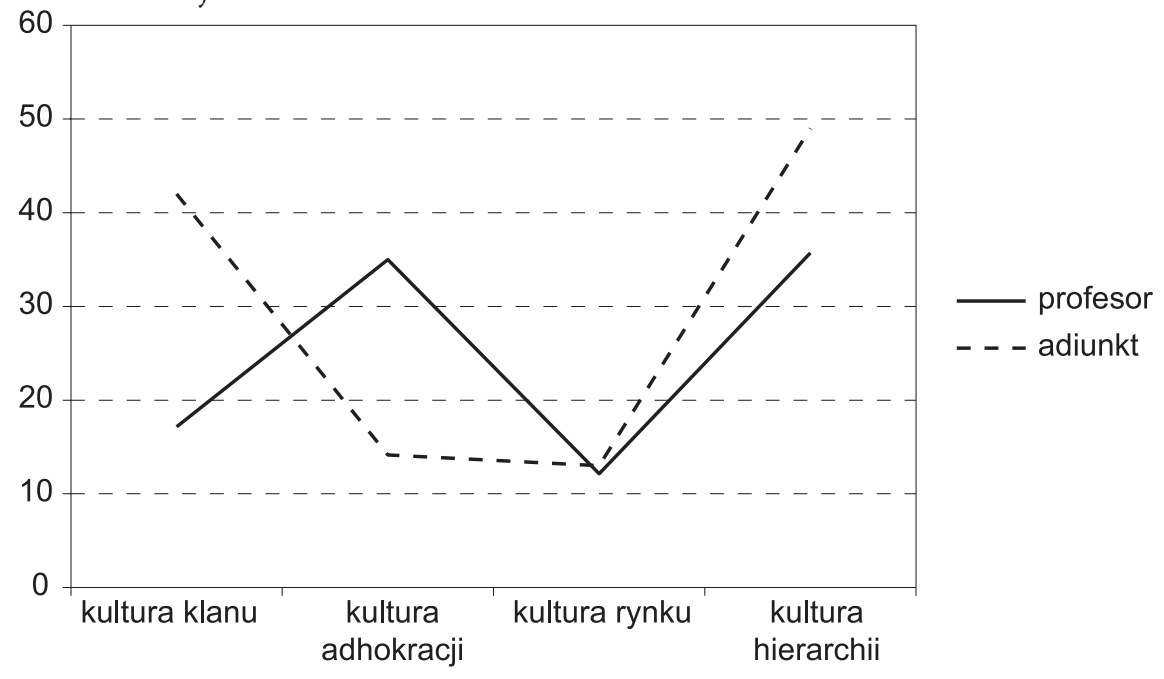

Rycina 7. Zależność między zajmowanym stanowiskiem a rodzajem kultury organizacyjnej w kontekście elementów, na które kładzie się nacisk w organizacji — stan obecny

Źródło: Opracowanie własne.

Takie stanowisko częściej charakteryzowało młodszych stopniem pracowników IP, co może wskazywać na potrzebę zmiany wyrażaną przez adiunktów. Płeć była nieistotnym predykatorem w kontekście wyrażania przez badanych stanu pożądanego w prezentowanym kontekście.

\section{F. Kryteria sukcesu w organizacji}

Jakie są kryteria sukcesu w IP? Zdaniem pracowników typami kultury, które je określają, są po raz kolejny kultura hierarchii i kultura klanu. W omawianym kontekście elementy kultury hierarchii konstytuujące kryteria sukcesu sprowadzają się do koncentracji na sprawach wewnętrznych, potrzebie stabilności i kontroli, a także przewidywalności. Jednocześnie ponad $1 / 3$ pracowników podkreśliła, iż kryteria sukcesu to zauważalna wspólnotowość w funkcjonowaniu IP i spójność. Ponadto część badanych wskazująca na elementy kultury klanu odwołała się do istniejących w Instytucie rozwiązań, które polegają na nagradzaniu pracowników na podstawie osiągnięć.

Jednocześnie zdaniem badanych o sukcesie w najmniejszym stopniu decyduje nastawienie na innowacje, nowatorskie rozwiązania i osiąganie pozycji lidera w dziedzinie innowacyjności. 
Tabela 6. Kryteria sukcesu w organizacji

\begin{tabular}{l|c|c}
\hline \multicolumn{1}{c|}{$\begin{array}{c}\text { Typ kultury } \\
\text { wyniki }\end{array}$} & Stan obecny & Stan pożądany \\
\hline A - klan & 32,56 & 37,83 \\
\hline B - adhokracja & 15,13 & 35,40 \\
\hline C - rynek & 16,48 & 14,72 \\
\hline D - hierarchia & 35,81 & 12,29 \\
\hline \multicolumn{2}{c}{ Źródło: Opracowanie własne. }
\end{tabular}

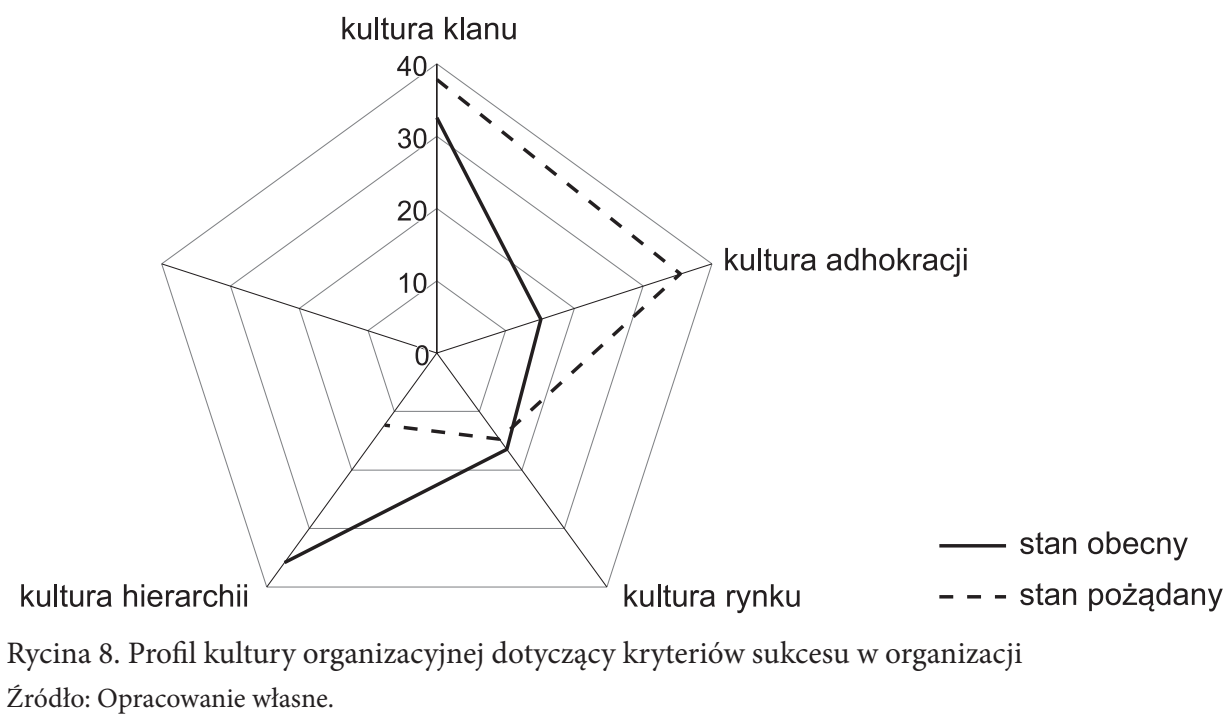

Rozkład odpowiedzi oddanych na poszczególne typy kultury organizacyjnej nie różniły się ze względu na płeć badanych. Zarówno kobiety, jak i mężczyźni wskazali, iż występujące obecnie kryteria sukcesu w Instytucie są projekcją kultury hierarchii, następnie klanu, rynku i w najmniejszym stopniu adhokracji.

Odmienne wskazania charakteryzują zaś badaną populację w kontekście zajmowanego stanowiska. Okazuje się bowiem, iż odpowiedzi udzielone przez adiunktów i profesorów różnią się w znacznym zakresie (zob. ryc. 9). Dla osób mających tytuł profesora kryteria sukcesu w Instytucie sprowadzają się do istoty kultury klanu, adiunktów zaś - hierarchii. Tym samym pracowników IP charakteryzują dwa odmienne podejścia w ocenie bieżących kryteriów sukcesu, wskazujące na istnienie wyraźnych rozbieżności w postrzeganiu tego samego zagadnienia. Można zaproponować hipotezę, iż przyczyną występujących różnic są odmienne praktyki wynikające z posiadanego doświadczenia naukowego poszczególnych osób, czasu pracy w Instytucie oraz charakteru relacji w strukturze IP. Najprawdopodobniej adiunkci, w większości niebędący samodzielnymi pracownikami naukowymi, postrzegają Instytut jako jednostkę, w której dominuje kultura hierarchii ze względu na obowiązującą ścieżkę awansu zawodowego, w której duże 
znaczenie mają procedury i wysoki stopień scentralizowania decyzji. Profesorowie natomiast — bardziej niezależni w strukturze uniwersytetu i ścieżce dalszej kariery naukowej oraz pełniący często funkcje mentorów i opiekunów - wskazują, że obowiązującym typem kultury organizacyjnej jest kultura klanu.

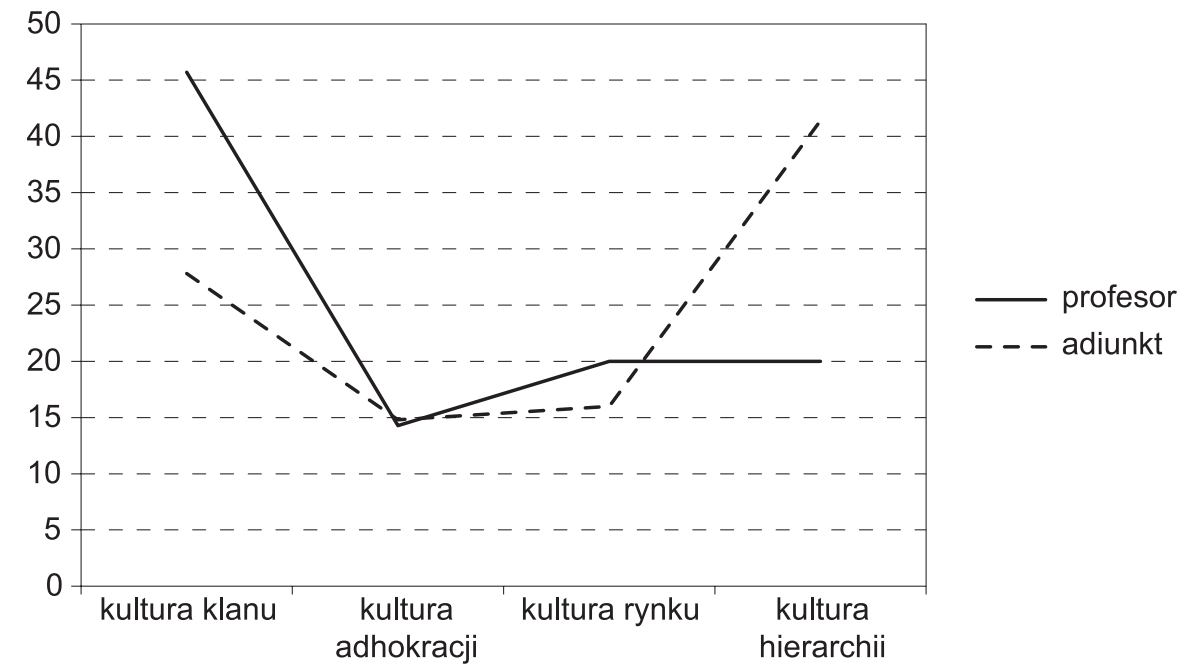

Rycina 9. Zależność między zajmowanym stanowiskiem a rodzajem kultury organizacyjnej w kontekście kryteriów sukcesu w Instytucie Politologii — stan obecny

Źródło: Opracowanie własne.

Według stanu pożądanego dominującymi typami kultury są klan i adhokracja, a najmniej preferowanymi kultury hierarchii i rynku. Zadeklarowanie takiego stanowiska cechowało zarówno kobiety, jak i mężczyzn, a także adiunktów oraz osoby z tytułem profesora. Uznanie przez część respondentów kultury klanu za najbardziej pożądany model wskazuje, że pracownicy IP $\mathrm{w}$ większości chcieliby, aby sukces $\mathrm{w}$ organizacji uwarunkowany był zaangażowaniem, pracą zespołową, realizacją wspólnych celów i silnych więzów. Zwolennicy adhokracji jako najbardziej pożądanego typu kultury organizacyjnej zwracają uwagę na innowacje, odpowiednie reagowanie na zmiany, kreatywność, elastyczność i niestandardowe rozwiązania w osiąganiu sukcesu w organizacji.

\section{Podsumowanie}

Wykorzystany na potrzeby badania kwestionariusz ankiety Camerona i Quinna pozwolił na dokonanie diagnozy kultury organizacyjnej Instytutu Politologii Uniwersytetu Wrocławskiego - zarówno w ramach sześciu podstawowych obszarów badawczych, jak i w odniesieniu do postawionych hipotez badawczych.

Wyniki badań pozwalają stwierdzić, że pracownicy IP, dokonując oceny obecnego stanu funkcjonowania Instytutu, wskazali, iż dominującym rodzajem kultury organiza- 
cyjnej we wszystkich sześciu poddanych analizie obszarach, a mianowicie: charakterystyki organizacji, stylu przywództwa w Instytucie, zarządzania pracownikami, spójności w miejscu pracy, elementów, na które kładzie się największy nacisk w Instytucie, oraz kryteriów sukcesu, jest kultura hierarchii, pożądanym stylem organizacyjnym zaś we wskazanych obszarach jest przede wszystkim styl charakterystyczny dla kultury klanu lub adhokracji. Można zatem stwierdzić, iż wyrażone przez pracowników IP stanowiska cechuje wyraźna rozbieżność między oceną obecnego stanu we wskazanych obszarach a stanem pożądanym. Tym samym uzyskane wyniki badań pozwalają stwierdzić, iż obecnie zogniskowane funkcjonowanie Instytutu, oparte na hierarchiczności, wysokim stopniu sformalizowania, swego rodzaju trwałości i przewidywalności, powinno ulec zmianie.

Istota wprowadzonych zmian sprowadza się zarówno do możliwości rozwoju zasobów ludzkich, pracy zespołowej, zaangażowania pracowników i troski o ludzi, wprowadzania nowych rozwiązań w funkcjonowaniu Instytutu w oparciu o nowoczesne metody pracy i jej organizacji, jak i reagowania na zmiany, które mają miejsce w otaczającej nas rzeczywistości. Ponadto $\mathrm{w}$ ramach stanu pożądanego pracownicy IP wskazują na potrzebę zarządzania organizacją oraz pracownikami, opartą zarówno na elastyczności, jak i innowacyjności. Wprowadzenie tego rodzaju zmian usprawniłoby zatem nie tylko zarządzanie w IP, lecz także wpłynęłoby na pracę samych pracowników. Ponadto otwartość na zmiany jest obecnie traktowana jako jeden z podstawowych atrybutów nowoczesnego zarządzania zasobami ludzkimi.

Warto też podkreślić, iż płeć jawi się jako zmienna różnicująca odpowiedzi pracowników Instytutu Politologii w istotnym zakresie tylko w niektórych przypadkach. Różnice ze względu na ten predykator zauważalne były szczególnie w kontekście wskazań odnoszących się do oceny stylu przywództwa występującego w IP. W przypadku pozostałych odpowiedzi płeć pracowników okazała się nieistotnym kryterium różnicującym badaną populację. Na obecnym etapie badań można zatem stwierdzić, iż na ocenę funkcjonowania pracowników w IP płeć wpływa tylko w jednym obszarze, w pozostałych wrażliwość na występowanie określonych atrybutów poszczególnych rodzajów kultur zależna jest od zajmowanego stanowiska, a nie od identyfikacji płciowej. Oznacza to zatem, iż wtórnym kryterium dokonywanej oceny jest płeć, istotnym natomiast zajmowane stanowisko.

W świetle tak wyrażonych stanowisk można stwierdzić, iż pracowników Instytutu Politologii cechuje wysoka świadomość potrzeby wprowadzenia zmian w jego funkcjonowaniu. Pracownicy IP jawią się jako populacja akcentująca swobodę działania oraz potrzebę elastyczności w pracy własnej i w ramach organizacji. 


\section{Bibliografia}

Cameron K.S., Quinn R.E., Kultura organizacyjna - diagnoza i zmiana. Model wartości konkurujących, przeł. B. Nawrot, Kraków 2006.

Deal T.E., Kennedy A.A., Corporate Culture: The Rites and Rituals of Corporate Life, New York 1982.

Dessler G., Turner A., Human Resource Management in Canada, Scarborough, Ontario 1992.

Griffin R.W., Podstawy zarzadzania organizacjami, przeł. M. Rusiński, Warszawa 1996.

Habuda L., Organizacyjno-kulturowe orientacje samorządowców i demokratyzm polskiego terytorialnego samorzadu, [w:] Samorząd terytorialny na przełomie XX/XXI wieku, red. A. Lutrzykowski, M. Popławski, R. Gawłowski, Toruń 2010.

Harrison R., Understanding your organization's character, „Harvard Business Review”, maj-czerwiec 1972.

Kroeber A.L., Kluckhohn C., Culture: A critical review of concepts and definitions, "Papers of the Peabody Museum of American Archeology and Ethnology” XLVII, nr 1, Cambridge, Massachusetts 1952.

Leśniewski M.A., Wyznaczanie profilu kultur organizacyjnych $z$ wykorzystaniem modelu K.S. Camerona i R.E. Quinna, na przykładzie urzędów gmin regionu świętokrzyskiego - wyniki badań ankietowych, „Studia i Prace Kolegium Zarządzania i Finansów" 2010, z. 104.

Marek M.A., Model wartości konkurujących w badaniu kultury organizacji samorządowych, „Roczniki Ekonomii i Zarządzania" 6 (42), 2014, nr 2.

Mikuła B., Klimat organizacyjny a kultura organizacyjna - próba systematyzacji pojęć, „Zeszyty Naukowe Małopolskiej Wyższej Szkoły Ekonomicznej w Tarnowie" 2000, nr 3.

Schein E.H., Organizational Culture and Leadership, Jossey-Bass, San Francisco-London 2004.

Serafin K., Kultura organizacyjna jako element wspierający realizację strategii przedsiębiorstwa, „Studia Ekonomiczne. Zeszyty Naukowe Uniwersytetu Ekonomicznego w Katowicach” 2015, nr 222.

Sikorski C., Kultura organizacyjna, Warszawa 2002.

Sikorski C., Organizacja, kultura, mentalność pracowników, „Problemy Organizacji” 1985, nr 3-4.

Stompór-Świderska J., Diagnoza kultury organizacyjnej uniwersytetu: elastyczne podejście do kierunków zmian i nowych wyzwań, [w:] Sukces w zarządzaniu kadrami. Elastyczność w zarzadzaniu kapitałem ludzkim, t. 2. Problemy zarzadczo-ekonomiczne, red. T. Listwan, M. Stor, Wrocław 2012.

Stompór-Świderska J., Kultura organizacyjna instytutu naukowego w percepcji studentów. Diagnoza i nowe wyzwania, „Management” 16, 2012, nr 1.

Stoner J.A.F., Freeman D.E., Gilbert D.R. jr, Kierowanie, przeł. A. Ehrlich, Warszawa 1998.

STRATEGOR, Zarządzanie firma, strategie, struktury, decyzje, tożsamość, przeł. K. Bolesta-Kukułka, Warszawa 1995.

Sułkowski Ł., Kulturowa zmienność organizacji, Warszawa 2002.

Worach A., Kultura organizacyjna, [w:] Zespót - kultura - projekt, red. W. Olejniczak, Szczecin 2009.

Zarządzanie. Teoria i praktyka, red. A.K. Koźmiński, W. Piotrowski, Warszawa 2000.

\section{Źródło internetowe}

Kultura organizacyjna, [hasło w:] Encyklopedia zarządzania, https://mfiles.pl/pl/index.php/Kultura_organizacyjna.

Wrocławskie Studia Politologiczne 21, 2016

(C) for this edition by CNS 


\section{Organizational culture of a scientific institute. A study of organizational culture in the Institute of Political Science at the University of Wrocław}

Keywords: organization, organizational culture, hierarchy, clan, adhocracy, market, change in organizational culture

Summary

In the article the conslusions coming from the research into organisational culture, conducted in the Institute of Political Science at the University of Wrocław were presented. The employed research instrument was the OCAI questionnaire, created by Kim S. Cameron and Robert S. Quinn, which allows to diagnose the incidence of particular elements of organisational culture as well as to identify the types of this culture. The research results point that - currently - the Institute's dominant form of organisational culture is the hierarchy culture, while the desired one is the clan and adhocracy culture. 